Research Article

\title{
Incidence and Audit of Treatment on Third and Fourth Grade Perineal Tear
}

\author{
Insidensi dan Audit dari Tata Laksana Ruptur Perineum Derajat Tiga dan Empat
}

\author{
Budi I Santoso, Satriyo Pamungkas
}

Department of Obstetrics and Gynecology

Faculty of Medicine Universitas Indonesia

Dr. Cipto Mangunkusumo Hospital

Jakarta

\begin{abstract}
Objective: To describe the incidence of $3^{\text {rd }}$ and $4^{\text {th }}$ grade perineal tear in Dr. Cipto Mangunkusumo hospital on the period of 2011 . 2014 and its compatibility of treatment based on RCOG guidelines.

Methods: Data were collected through medical records on women who had vaginal delivery in Dr. Cipto Mangunkusumo hospital from January 2011 to December 2014. This was a descriptive study with cross sectional design.

Results: The incidence of $3^{\text {rd }}$ and $4^{\text {th }}$ grade perineal tear each year were $3.55 \%, 4.35 \%, 3.95 \%$, and $1.77 \%$ consecutively. About $100 \%$ treatment were accompanied by consultant; $3.5 \%$ performed in operating theatre; $90.7 \%$ were given postoperative antibiotic; $42.2 \%$ were given urinal catheter in $1 \times 24$ hour postoperative; $100 \%$ were given analgesic. About $61.4 \%$ of procedures were not compatible with RCOG guidelines.

Conclusion: The study showed that the incidence of $3^{\text {rd }}$ and $4^{\text {th }}$ grade of perineal tear was $3.66 \%$ for 4 years and the compliance to RCOG standard was $38.6 \%$.

[Indones J Obstet Gynecol 2017; 5-1: 35-41]

Keywords: incidence, RCOG, third and fourth grade of perineal tear, treatment
\end{abstract}

\begin{abstract}
Abstrak
Tujuan: Untuk mengetahui insidensi robekan perineum tingkat III dan IV di RSUPN Dr. Cipto Mangunkusumo pada tahun 2011 - 2014 dan kesesuaian tata laksana berdasarkan panduan RCOG.

Metode: Data diambil melalui rekam medis pada perempuan yang menjalani kelahiran di RSUPN Dr. Cipto Mangunkusumo pada bulan Januari 2011 - Desember 2014. Penelitian ini merupakan studi deskriptif dengan desain potong lintang.

Hasil: Insidensi robekan perineum tingkat III dan IV per tahun sebesar 3,55\%; 4,35\%; 3,95\%; dan 1,77\%. Sebanyak 100\% penjahitan robekan perineum tingkat III dan IV dihadiri konsultan; 3,5\% penjahitan di kamar operasi; 90,7\% diberikan antibiotik pascaoperasi; 42,2\% dipasang kateter 1X24 jam pascaoperasi; 100\% diberikan analgetik. Sebanyak 61,4\% subjek tidak ditata laksana sesuai standar RCOG tahun 2015.

Kesimpulan: Studi ini menunjukkan bahwa insidensi robekan perineum tingkat III dan IV sebesar 3,66\% dalam 4 tahun dan kepatuhan mengikuti standar RCOG sebesar 38,6\%.

[Maj Obstet Ginekol Indones 2017; 5-1: 35-41]

Kata kunci: insidensi, RCOG, robekan perineum tingkat III dan IV, tata laksana
\end{abstract}

\section{INTRODUCTION}

Third and fourth grade perineal tear involves the anal sphincter and epithelium which occurred from $0.1 \%$ to $10.2 \%$ of vaginal delivery. The incidence of $3^{\text {rd }}$ and $4^{\text {th }}$ grade perineal tear in United Kingdom was $2.9 \%$ (between $0-8 \%$ ); whereas, $6.1 \%$ happened in primiparous and $1.7 \%$ in multiparous women. ${ }^{1,2}$ Meanwhile, the incidence of $3^{\text {rd }}$ and $4^{\text {th }}$ grade of perineal tear in Austria were $1.5 \%$ and $0.1 \%$, respectively. ${ }^{3}$ The incidence of anal sphincter tear in mediolateral episiotomy population was $1.7 \%(2.9 \%$ on primiparous women) and $12 \%$ (19\% on primiparous women) in mediana episiotomy population., ${ }^{1,2}$

The $3^{\text {rd }}$ and $4^{\text {th }}$ grade perineal tear often induces morbidity for women so that it influences the quality of life. Serious complication on vaginal delivery caused by perineal tear consists of fecal incontinence, pelvic disorders, dyspareuni, chronic pain, and finally it inflicts to social and severe psychological problem. ${ }^{1,4,5}$ An audit in national referral hospital in Jamaika showed that women suffered from high morbidity (43\%) and fecal incontinence $(23 \%)$ after the anal sphincter repair surgery. ${ }^{6}$

Based on high morbidity caused by perineal tear, several studies conducted an audit of appropriate treatment in $3^{\text {rd }}$ and $4^{\text {th }}$ grade perineal tear. The goal of this audit was to improve the service quality and decrease the morbidity referring to practical guideline. The audit in national referral hospital in Jamaika pointed out there were 26 women 
suffering from anal sphincter tear; 9 cases (34.6\%) reached the doctor compliance scores more than 6 and 17 cases (65.4\%) got the scores 6 or lower. All perineal tears in this study was treated by experience doctor. ${ }^{6}$ Nora $\mathrm{G}$ and Iram S in 2013 did the audit to assess the treatment of anal sphincter repairment. In general, most cases were done following the valid guidelines; however, the documentation about operator, suture technique, and suture material on some subjects were not recorded in medical records. For internal anal sphincter repair technique, the compliance rate reached 21.9\%; meanwhile, the others were not recorded or stated in medical records. ${ }^{7}$

Royal College of Obstetricians and Gynaecologist (RCOG) released the guidelines of $3^{\text {rd }}$ and $4^{\text {th }}$ grade perineal tear in $2015 .{ }^{3}$ The guidelines stated the recommendation of perineal tear pre, intra, and post-surgery. Therefore, this study is conducted to determine the incidence of $3^{\text {rd }}$ and $4^{\text {th }}$ grade perineal tear in Dr. Cipto Mangunkusumo hospital from 2011 to 2014 and the appropriate treatment to RCOG guideline in 2015.

\section{METHODS}

This cross-sectional study was conducted in Dr. Cipto Mangunkusumo hospital by taking the secondary data from medical records on the period of January 2011 until December 2014. The sample was taken by consecutive sampling involving all subjects fulfilling inclusion criteria. Inclusion criteria on this study were all post vaginal delivery women which the data were completely recorded in medical records. By using formula, the minimal subjects were 270 women.

Third grade of perineal tear is defined by laceration starting from mucosal, perineal muscle, to anal sphincter which consists of IIIA grade: laceration less than $50 \%$ of external anal sphincter muscle; IIIB grade: laceration $50 \%$ or more of external anal sphincter muscle; and IIIC: laceration until internal anal sphincter muscle. Meanwhile, $4^{\text {th }}$ grade of perineal tear is laceration from mucosal, perineal muscle, external and internal anal sphincter muscle, to rectal mucosal.

A proper treatment of $3^{\text {rd }}$ and $4^{\text {th }}$ grade perineal tear was assessed based on 9 components stated in RCOG guidelines, namely consultant attendance, repairment location, anesthesia application, suture technique, suture material, post-operative antibiotic, urinal catheter insertion in $1 \times 24$ hour, sodium diclofenac analgesic, and laxatives using. The treatment was appropriate if fulfilling 7 of 9 criteria stated above.

The descriptive data was consisted of categorical variables (frequency and percentage of appropriate treatment to RCOG guidelines, consultant attendance, repairment location, anesthesia technique, anorectal mucosal suture technique, internal and external anal sphincter mucosal suture technique, suture material, postoperative antibiotic, urinal catheter insertion in 1x24 hour, analgesic and laxatives application, perineal tear classification, head fetal denominator, and induction of labor) and numerical variables (maternal age, number of parity, and time of phase II labor). The data was distributed by using SPSS 20 (IBM).

This study had got the ethical approval from Komisi Etik Fakultas Kedokteran Universitas Indonesia (FK UI) RSUPN Dr. Cipto Mangunkusumo number 1019/UN2.F1/ETIK/2015.

\section{RESULTS}

From 6,095 deliveries recorded on this study, there were 223 subjects $(3.66 \%)$ experienced $3^{\text {rd }}$ and $4^{\text {th }}$ grade perineal tear. From 2011 to 2014, the incidence of perineal tear was $3.55 \%, 4.35 \%$, $3.95 \%$, and $1.77 \%$, respectively. There were 18 subjects which not completely recorded so that the data were excluded from this study. The mean of maternal age was 25.3 (SD 6.5) years old in 2011 and 26.6 (SD 5.2) years old in 2014. Between 2011 and 2014, the subject was dominated by primiparous women (64.7\% to $87.5 \%)$. The subject undergoing normal delivery was more than the women doing induction of labor with misoprostol, oxytocin, and both. In 2011 and 2012, most women suffering from perineal tear delivered spontaneously (66.7\% and 59.1\%); however; in 2013 and 2014, the proportion of women experiencing perineal tear from vacuum extraction delivery reached $56.9 \%$ and 47.1\%. The mean birth weight from 2011 to 2014 was 3,$238 ; 3,234 ; 3,124$; and 3,090 grams; consecutively. The IIIA grade perineal tear ranked the most from 2011 to 2014 which proportion was $45.2 \%$; $45.2 \%, 70.8 \%$, and $82.4 \%$, respectively. (Table 1 )

The incidence of $3^{\text {rd }}$ and $4^{\text {th }}$ grade perineal tear on primiparous women tended to decrease; namely $87.5 \%$ in $2011,79.6 \%$ in $2012,75.4 \%$ in 2013 , and 
Table 1. The Characteristics of Delivery in Dr. Cipto Mangunkusumo Hospital on the Period of 2011-2014

\begin{tabular}{|c|c|c|c|c|}
\hline Characteristics & $2011(n=48)$ & $2012(n=93)$ & $2013(n=65)$ & $2014(n=17)$ \\
\hline Maternal age & $25.3(6.5)$ & $26.5(5.6)$ & $26.6(5.2)$ & $26.6(5.2)$ \\
\hline \multicolumn{5}{|l|}{ (mean (SD)) (years old) } \\
\hline Gestational age (mean (SD)) (weeks) & $38.7(1.3)$ & $38.9(1.3)$ & $38.8(1.4)$ & $39.0(1.6)$ \\
\hline \multicolumn{5}{|l|}{ Parity } \\
\hline Primiparous & $42(87.5 \%)$ & $74(79.6 \%)$ & $49(75.4 \%)$ & $11(64.7 \%)$ \\
\hline Multiparous & $6(12.5 \%)$ & $19(20.4 \%)$ & $16(24.6 \%)$ & $6(35.3 \%)$ \\
\hline \multicolumn{5}{|l|}{ Induction of labor } \\
\hline Without induction & $26(54.2 \%)$ & $58(62.4 \%)$ & $32(49.2 \%)$ & $11(64.7 \%)$ \\
\hline Misoprostol & $10(20.8 \%)$ & $13(14.0 \%)$ & $14(21.5 \%)$ & $2(17.6 \%)$ \\
\hline Oxytocin & $10(20.8 \%)$ & $17(18.3 \%)$ & $18(27.7 \%)$ & $2(11.8 \%)$ \\
\hline Misoprostol + Oxytocin & $2(4.2 \%)$ & $5(5.4 \%)$ & $1(1.5 \%)$ & $1(5.9 \%)$ \\
\hline \multicolumn{5}{|l|}{ Methods of delivery } \\
\hline Spontaneous & $32(66.7 \%)$ & $55(59.1 \%)$ & $11(16.9 \%)$ & $3(17.6 \%)$ \\
\hline Vacuum & $2(8.3 \%)$ & $22(23.7 \%)$ & $37(56.9 \%)$ & $8(47.1 \%)$ \\
\hline Forceps & $12(25.0 \%)$ & $16(17.2 \%)$ & $17(26.2 \%)$ & $6(35.3 \%)$ \\
\hline Birth weight & 3,238 (459.8) & 3,234 (445.9) & $3,124(427.8)$ & 3,090 (301.6) \\
\hline \multicolumn{5}{|l|}{ (mean (SD)) (grams) } \\
\hline \multicolumn{5}{|l|}{ Perineal tear } \\
\hline IIIA grade & $28(45.2 \%)$ & $42(45.2 \%)$ & $46(70.8 \%)$ & $14(82.4 \%)$ \\
\hline IIIB grade & $10(20.8 \%)$ & $32(34.4 \%)$ & $11(16.9 \%)$ & $2(11.8 \%)$ \\
\hline IIIC grade & $5(10.4 \%)$ & $3(3.2 \%)$ & $5(7.7 \%)$ & $1(5.8 \%)$ \\
\hline IV grade & $5(10.4 \%)$ & $16(17.2 \%)$ & $3(4.6 \%)$ & $0(0 \%)$ \\
\hline $\begin{array}{l}\text { Incidence of } 3^{\text {rd }} \text { and } 4^{\text {th }} \text { grade } \\
\text { of perineal tear }\end{array}$ & $3.55 \%$ & $4.35 \%$ & $3.95 \%$ & $1.77 \%$ \\
\hline Vaginal delivery & 1,354 & 2,138 & 1,645 & 958 \\
\hline
\end{tabular}

$64.7 \%$ in 2014. Meanwhile, on multiparous women, the incidence of it raised gradually from $12.5 \%$ in 2011 to $35.3 \%$ in 2014.

In 2014, the most subjects encountered $3^{\text {rd }}$ and $4^{\text {th }}$ grade perineal tear were due to vacuum extraction with episiotomy. Different from 2011, all subjects got this tear due to forceps extraction without episiotomy.

Table II showed the proportion of $3^{\text {rd }}$ and $4^{\text {th }}$ grade perineal tear patients which was treated correctly to RCOG guidelines in 2015. This study pointed out that almost half of subjects (42.2\%) were not handled properly to RCOG guidelines. Discrepancy was found in surgery location, expert operator, and catheter insertion in 1x24 hour postsurgery. From 2011 to 2014, 96.5\% from suturing of $3^{\text {rd }}$ and $4^{\text {th }}$ grade perineal tear was conducted in delivery room, not in operating theatre. The urine catheter insertion in $1 \times 24$ hour post-surgery was not applied in $57.8 \%$ women. All procedure in this study was done by obstetrics and gynecology residents.
All procedures were using anesthesia application; whereas, almost all of them (96.4\%) were performed by local anesthesia. Starting from 2011 to $2014,100 \%$ subjects were stitched by simple interrupted technique on anorectal mucosal. To stitch internal anal sphincter muscle, only 2 subjects $(5.3 \%)$ got the simple interrupted methods; meanwhile, 36 subjects (94.7\%) were stitched with horizontal mattress suture.

In this study, all subjects were reported for the external anal sphincter muscle stitches which using overlapping technique $(41.7 \%)$ and end to end technique (58.3\%). For external anal sphincter muscle, almost all subjects were stitch using PGA 2.0 (99.6\%). All subjects got sodium diclofenac analgesic and laxatives in this study. Only 92 subjects $(42.2 \%)$ got the insertion of urinal catheter in $1 \times 24$ hour post repairment. All subjects obtained amoxicillin-clavulanate; whereas, only $9.3 \%$ subjects also got metronidazole as an additional antibiotic. 
Table 2. The Proportion of Approriate Treatment on $3^{\text {rd }}$ and $4^{\text {th }}$ Grade Perineal Tear Patients in Dr. Cipto Mangunkusumo Hospital on the Period of 2011-2014 to RCOG Guidelines in 2015

\begin{tabular}{|c|c|c|c|c|c|c|}
\hline Parameter & & $2011 \mathrm{n}(\%)$ & 2012 n(\%) & 2013 n(\%) & $2014 \mathrm{n}(\%)$ & Total \\
\hline \multirow[t]{2}{*}{ Operator } & resident $\mathrm{T} 1-2$ & 47 (97.9\%) & $91(97.9 \%)$ & 67 (98.5\%) & $17(100 \%)$ & $219(98.2 \%)$ \\
\hline & resident T3-4 & $1(2.1 \%)$ & $2(2.1 \%)$ & $1(1.5 \%)$ & $0(0 \%)$ & $4(1.8 \%)$ \\
\hline \multirow{2}{*}{$\begin{array}{l}\text { Perineal tear } \\
\text { documentation }\end{array}$} & Yes & $48(100 \%)$ & $93(100 \%)$ & $68(100 \%)$ & $17(100 \%)$ & $226(100 \%)$ \\
\hline & No & $0(0 \%)$ & $0(0 \%)$ & $0(0 \%)$ & $0(0 \%)$ & $0(0 \%)$ \\
\hline $\begin{array}{l}\text { Consultant } \\
\text { attendance }\end{array}$ & & $48(100 \%)$ & $93(100 \%)$ & $68(100 \%)$ & 17 (100\%) & $226(100 \%)$ \\
\hline \multirow{2}{*}{$\begin{array}{l}\text { Proof of consultant } \\
\text { not attended }\end{array}$} & Yes & $48(100 \%)$ & $93(100 \%)$ & $68(100 \%)$ & $17(100 \%)$ & $226(100 \%)$ \\
\hline & No & $0(0 \%)$ & $0(0 \%)$ & $0(0 \%)$ & $0(0 \%)$ & $0(0 \%)$ \\
\hline \multirow[t]{2}{*}{ Repairment location } & Delivery room & 47 (97.9\%) & $87(93.5 \%)$ & 67 (98.5\%) & 17 (100\%) & $218(96.5 \%)$ \\
\hline & Operating theatre & $1(2.1 \%)$ & $6(6.5 \%)$ & $1(1.5 \%)$ & $0(0 \%)$ & $8(3.5 \%)$ \\
\hline \multirow[t]{2}{*}{ Anesthesia application } & Local & 47 (97.9\%) & $87(93.5 \%)$ & 67 (98.5\%) & 17 (100\%) & $218(96.5 \%)$ \\
\hline & Spinal & $1(2.1 \%)$ & $6(6.5 \%)$ & $1(1.5 \%)$ & $0(0 \%)$ & $8(3.6 \%)$ \\
\hline $\begin{array}{l}\text { Anorectal mucosa } \\
\text { stitch method }\end{array}$ & Interupted & $5(100 \%)$ & $16(100 \%)$ & $3(100 \%)$ & $0(0 \%)$ & $24(100 \%)$ \\
\hline \multirow{2}{*}{$\begin{array}{l}\text { Internal anal sphincter } \\
\text { muscle stitch method }\end{array}$} & Horizontal mattress & $9(90.0 \%)$ & $18(94.7 \%)$ & $8(100 \%)$ & $1(100.0 \%)$ & $36(94.7 \%)$ \\
\hline & Interupted & $1(10.0 \%)$ & $1(5.3 \%)$ & $0(0 \%)$ & $0(0 \%)$ & $2(5.3 \%)$ \\
\hline \multirow{2}{*}{$\begin{array}{l}\text { External anal sphincter } \\
\text { muscle stitch method }\end{array}$} & Overlapping & $20(41.7 \%)$ & $51(54.8 \%)$ & $19(29.2 \%)$ & $3(17.6 \%)$ & $93(41.7 \%)$ \\
\hline & End to end & $28(58.3 \%)$ & $42(45.2 \%)$ & $46(70.8 \%)$ & $14(82.4 \%)$ & $130(58.3 \%)$ \\
\hline \multirow{2}{*}{$\begin{array}{l}\text { Suture material for } \\
\text { anorectal mucosal }\end{array}$} & PGA 2.0 & $0(0 \%)$ & $13(81.3 \%)$ & $0(0 \%)$ & $0(0 \%)$ & $13(54.2 \%)$ \\
\hline & PGA 3.0 & $5(100 \%)$ & $3(18.7 \%)$ & $3(100 \%)$ & $0(0 \%)$ & $11(45.8 \%)$ \\
\hline \multirow{2}{*}{$\begin{array}{l}\text { Suture material for } \\
\text { internal anal sphincter }\end{array}$} & PGA 2.0 & $9(90.0 \%)$ & $19(100 \%)$ & $8(100 \%)$ & $1(100 \%)$ & $37(97.4 \%)$ \\
\hline & PGA 3.0 & $1(10.0 \%)$ & $0(0 \%)$ & $0(0 \%)$ & $0(0 \%)$ & $1(2.6 \%)$ \\
\hline \multirow{2}{*}{$\begin{array}{l}\text { Suture material for } \\
\text { external anal sphincter }\end{array}$} & PGA 2.0 & $47(97.9 \%)$ & $93(100 \%)$ & $65(100 \%)$ & $17(100 \%)$ & $222(99.6 \%)$ \\
\hline & PGA 3.0 & $1(2.1 \%)$ & $0(0 \%)$ & $0(0 \%)$ & $0(0 \%)$ & $1(0.4 \%)$ \\
\hline \multicolumn{7}{|c|}{ Post-operative treatment } \\
\hline \multirow{2}{*}{$\begin{array}{l}\text { Antibiotic post- } \\
\text { operative }\end{array}$} & Co-amoxiclav & $47(97.9 \%)$ & $80(86.0 \%)$ & $63(92.6 \%)$ & $15(88.2 \%)$ & $205(90.7 \%)$ \\
\hline & $\begin{array}{l}\text { Co-amoxiclav + } \\
\text { Metronidazole }\end{array}$ & $1(2.1 \%)$ & $13(14.0 \%)$ & $5(7.4 \%)$ & $2(11.7 \%)$ & $21(9.3 \%)$ \\
\hline \multirow{2}{*}{$\begin{array}{l}\text { Urinal catheter } \\
\text { insertion in } 1 \times 24 \text { hour }\end{array}$} & Yes & $19(39.6 \%)$ & $42(45.2 \%)$ & $25(36.8 \%)$ & $8(53.3 \%)$ & $94(42.2 \%)$ \\
\hline & No & $29(60.4 \%)$ & $51(54.9 \%)$ & $40(61.5 \%)$ & $9(52.9 \%)$ & $129(57.8 \%)$ \\
\hline \multirow[t]{2}{*}{ Sodium diclofenac analgesic } & Yes & $48(100 \%)$ & $93(100 \%)$ & $68(100 \%)$ & $17(100 \%)$ & $226(100 \%)$ \\
\hline & No & $0(0 \%)$ & $0(0 \%)$ & $0(0 \%)$ & $0(0 \%)$ & $0(0 \%)$ \\
\hline \multirow[t]{2}{*}{ Laxatives using } & Yes & 48 (100\%) & 93 (100\%) & $68(100 \%)$ & 17 (100\%) & $226(100 \%)$ \\
\hline & No & $0(0 \%)$ & $0(0 \%)$ & $0(0 \%)$ & $0(0 \%)$ & $0(0 \%)$ \\
\hline \multirow[t]{2}{*}{ Appropriate scores } & $\geq 7$ & $19(39.6 \%)$ & $34(36.6 \%)$ & 25 (38.5\%) & $8(47.1 \%)$ & $86(38.6 \%)$ \\
\hline & $<7$ & $29(60.4 \%)$ & $59(63.4 \%)$ & $40(61.5 \%)$ & $9(52.9 \%)$ & 137 (61.4\%) \\
\hline
\end{tabular}




\section{DISCUSSION}

The incidence of anal sphincter tear in this study was $3.66 \%$. For tertiary hospital, this incidence rate was higher than the rate published in RCOG guideline which was approximately $1 \%$. In Sweden and Finland, the incidence of $3^{\text {rd }}$ and $4^{\text {th }}$ grade perineal tear was only $2.69 \%$ and $0.36 \%$. Both of them were teaching hospital where the labor was done by midwife and perineal tear stitch was conducted by trainee. ${ }^{8}$ Nevertheless, the incidence rate which published in systematic review from 451 studies was higher than this rate. Fowler ${ }^{9}$ stated that in mediolateral episiotomy on delivery, the rate was ranged from $0.4 \%$ to $25 \%$. Meanwhile, the rate could be reached $19 \%$ on population done medial episiotomy.

In 2014, the incidence of $3^{\text {rd }}$ and $4^{\text {th }}$ grade perineal tear was the lowest rate of all years before, namely $1.77 \%$ due to the lowest mean of birth weight. Jander, et al. ${ }^{10}$ through their study said that the birth weight higher than 4,000 grams was the independent factor of anal sphincter tear. In another study, the birth weight higher than 3,325 grams was the most significant factors to increase anal levator muscle tear on three months after delivery. The proportional trend of primiparity and methods of delivery did not follow the trend of $3^{\text {rd }}$ and $4^{\text {th }}$ grade perineal tear although there was not analyzed statistically. ${ }^{11}$ This result was different from Parnelli, et al. ${ }^{12}$ which the decrease of incidence was influenced by the lower number of vacuum extraction and the improvement of delivery methods. O'Herlihy ${ }^{13}$ stated that primiparity was the main factor of anal sphincter tear. A lot of researches studied about the risk factors of perineal tear ${ }^{14}$; therefore, we needed to conduct the advanced analytic study to know the most influencing risk factors.

In this study, $3^{\text {rd }}$ and $4^{\text {th }}$ grade perineal tear was higher in primiparous women in accordance with study by Pyykonen. ${ }^{15}$ They stated that in primiparous women group with single life fetus in head presentation through spontaneous labor, the risk of $3^{\text {rd }}$ and $4^{\text {th }}$ grade of perineal tear was 1.4 times higher (OR 1.44; 95\% CI 1.28-1.61) than multiparous group. Based on methods of delivery in 2014, the most subjects got $3^{\text {rd }}$ and $4^{\text {th }}$ grade perineal tear coming from vacuum extraction with episiotomy. In primiparous women, episiotomy decreased the incidence rate of anal sphincter tear (OR 0.83; 95\% CI 0.72-0.92); however, episiotomy increased the risk of perineal tear (OR 2.01 95\% CI 1.67-2.44) in multiparous women. ${ }^{16}$ In another study, mediolateral episiotomy raised the risk almost 5 times higher to be $3^{\text {rd }}$ and $4^{\text {th }}$ grade perineal tear. Vacuum extraction increased 2.64 times risk to get $3^{\text {rd }}$ and $4^{\text {th }}$ grade perineal tear (OR 2.64; 95\% CI 1.25-5.54). ${ }^{17}$ In 2011, all subjects who did delivery by forceps extraction without episiotomy got $3^{\text {rd }}$ and $4^{\text {th }}$ grade of perineal tear. Christianson, et al. ${ }^{18}$ stated that forceps delivery and nulliparity were the risk factor of anal sphincter tear. In another study with large number of subjects, forceps extraction delivery was the strongest risk factor to be anal sphincter tear (OR 1.02; 95\% CI 3.6-28.9). ${ }^{16}$

This study was the first research in Indonesia which analyzed the treatment of $3^{\text {rd }}$ and $4^{\text {th }}$ grade perineal tear. Sellars ${ }^{19}$ said that to improve the clinical practice was through conducting an audit, collecting the data, analyzing it, and giving feedback. We could give feedback after analyzing the quality of service in an institution. Fernando, et al. $^{20}$ stated that to reduce the incidence rate of anal sphincter tear which impact to women's quality of life, they could choose vacuum extraction than forceps, limit the episiotomy procedure, and repair the anal sphincter tear by trained staff. These policies could be implemented after doing an audit to service and risk factors of perineal tear in each institution. The aim of this study is to give feedback so that it can improve the quality service of $3^{\text {rd }}$ and $4^{\text {th }}$ grade perineal tear. ${ }^{21}$

Although the consultant always attended the procedure, all perineal tear stitch on the subjects were done by residents, especially first and second grade of residents. Only 1.8\% stitch was performed by third and fourth grade of residents. In Dr. Cipto Mangunkusumo hospital, in basic step, all residents got the training about $3^{\text {rd }}$ and $4^{\text {th }}$ grade perineal tear. Andrews ${ }^{22}$ said that the outcome of anal sphincter tear stitch performed by doctor who had got the clinical practice was good. From 59 women, there were 6 subjects experiencing defect on ultrasonography; however, no one had the decrease symptom of fecal incontinence, urgency, or quality of life on one year ahead post-delivery. Fernando and Sultan ${ }^{20}$ stated that perineal tear stitch conducted by expert could decrease the procedural complication. In a survey carried out by Fischer, et al. ${ }^{23}$, trainee or residents had better knowledge than consultant about the definition of anal sphincter tear. High rate of stitch in delivery room 
was caused by higher rate of operating theatre for more emergency cases in Dr. Cipto Mangunkusumo hospital. There were still no written policies in Indonesia about a must to do $3^{\text {rd }}$ and $4^{\text {th }}$ grade of perineal tear stitch on operating theatre so that the place of procedure became the preference from operator and the availability of operating theatre.

Almost all stitches were done in delivery room (96.5\%). From 2011 to 2014, only 8 subjects $(3.5 \%)$ conducted the stitch on operating theatre. Compared to study by Cawich, et al. ${ }^{1}$, about $38.5 \%$ subjects did the stitch on the operating theatre. About $96.4 \%$ subjects used local anesthesia and the other used spinal anesthesia. From 10 patients did in operating theatre, 7 subjects used general anesthesia and the remaining got regional anesthesia, and 16 subjects was performed in delivery room. Based on RCOG Green-top guidelines number 29 , the $3^{\text {rd }}$ and $4^{\text {th }}$ grade perineal tear stitch should be conducted in operating theatre with regional or general anesthesia. $^{3}$

For the suture technique of internal anal sphincter muscle and anorectal mucosal, it was appropriate to the standard of procedural which anorectal mucosal was stitched by interrupted technique; meanwhile, most of internal anal sphincter muscle was approximated by horizontal mattress. In this study, the technique used to stitch the external anal sphincter was end to end or overlapping depending on the grade perineal tear. Based on RCOG guidelines, both of techniques gave the same outcome. ${ }^{3}$ Meanwhile, Jacobson ${ }^{24}$ concluded the overlapping technique could decrease the incidence of fecal incontinence ( $p=0.009$; RR 0.07; 95\% CI 0.00-1.21; NNT 4.2), urgency ( $\mathrm{p}=0.02$; RR 0.12; 95\% CI 0.02-0.86; NNT 3.6), and perineal pain ( $\mathrm{p}=0.04$; RR 0.08 ; $95 \% \mathrm{CI}$ $0.00-1.45$; NNT 5) significantly in 12 months after procedure. Vicryl ${ }^{\circledR}$ was the yarn using in this study. As standard on RCOG in 2015, the stitch using this yarn could give the better outcome. ${ }^{23}$

All subjects got the amoxicillin-clavulanate. A study by Cawich, et al. ${ }^{1}$ they gave the $2^{\text {nd }}$ and $3^{\text {rd }}$ generation of cephalosporin intra vein on single dose. Unfortunately, only $7.7 \%$ subjects got the antibiotic as standard guidelines; meanwhile, in another study, the antibiotic was administered more than 72 hours with different kinds. According to RCOG guidelines, the antibiotic should be provided as local protocol with broad spectrum which the aim was to reduce the incidence of wound dehiscence after procedure. ${ }^{3}$

On this study, there were 9 criteria to assess the compatibility of treatment to RCOG guidelines. All criteria could be evaluated objectively in medical records. Ideally, every subject was able to fulfill all of the criteria. Due to not applicable in clinical service, we set 7 of 9 criteria should be fulfilled. This score was taken based on Cawich, et al. ${ }^{1}$ study which more than 6 of 8 criteria were considered good according to the consensus from five experts who not involved in the study. On the consensus, they got the minimal score to be appropriate was 6.8 with SD 1.3. On the audit conducted in Leicester, United Kingdom, the appropriate score for operator, external anal sphincter stitch methods, suture location, suture material, and use of antibiotic were $100 \%, 92 \%, 98 \%, 90 \%$, and $100 \%$, respectively. ${ }^{25}$ In This study, 86 subjects $(38.6 \%)$ involved in the criteria appropriate to the RCOG standard. This rate was higher than number of subjects in study of Cawich, et al. ${ }^{1}$ which only 9 of 26 cases (34.6\%) was treated as RCOG guideline.

This study was the first study which conducted the audit to the treatment of $3^{\text {rd }}$ and $4^{\text {th }}$ grade perineal tear in tertiary hospital. High number of delivery in a year (more than 1,000 deliveries per year) gave the great description of the incidence rate of it in the real population. Almost all deliveries in our hospital was assisted by residents who had been trained to the same competence level as normal delivery care so that it could control the risk of anal sphincter tear from operator aspect. This data was taken for the last 4 years so that it could capture the whole service quality to be implemented in policy.

\section{CONCLUSION}

The study shows that the incidence of $3^{\text {rd }}$ and $4^{\text {th }}$ grade of perineal tear is $3.66 \%$ for 4 years and the compliance to RCOG standard is $38.6 \%$.

\section{Conflict of Interest}

The author(s) declared no potential conflicts of interest with respect to the research, authorship, and/or publication of this article. We received no financial support for the research, authorship, and/or publication of this article. 


\section{REFERENCES}

1. Cawich SO, Kulkarni S, Ramdass M, et al. An audit of clinician compliance with best practice recommendations to repair severe obstetric anal sphincter injuries. Perm J 2014; 18: 27-31.

2. Dharbamulla A, Bhal K. Audit on perineal injury involving anal sphincter complex and epithelium. Cardiff and Vale NHS trust, United Kingdom [online]. 2008 [cited 2015 Dec 21]; 423. Available from: https://www.ics.org/Abstracts/ Publish/46/000423.pdf

3. Royal College of Obstetricians \& Gynaecologists. The management of third and fourth degree perineal tears. Green top Guideline, 2015; 29: 1-19.

4. Aigmueller T, Umek W, Elenskaia K, et al. Guidelines for the management of third and fourth degree perineal tears after vaginal birth from the Austrian Urogynecology Working Group. Int Urogynecol J. 2013; 24: 553-8.

5. Trust NF. Episiotomy and perineal trauma repair. 2012: 2-6.

6. Kundu R, Slevin A, Yousif O, Ravikumar N. Clinical audit on the management of $3^{\text {rd }}$ and $4^{\text {th }}$ degree perineal tears over a period pf 5 years (2005-2009) (e-poster). Letterkenny General Hospital [online]. 2010 [cited 2015 Dec 21]. Available from: http://www.epostersonline.com/rcog2011/ ?q= node $/ 1431$

7. The Women's. Third and fourth degree tears management [serial online]. 2013 [cited 2015 Dec 21]. Available from: https://thewomens.r.worldssl.net/images/uploads/down loadable-records/clinical-guidelines/third-and-fourth-deg ree-tears-management.pdf

8. Pirhonen J, Grenman S, Haadem K, Gudmundsson S, Lindgvist P, Siihola $S$, et al. Frequency of anal sphincter rupture at delivery in Sweden and Finland - result of difference in manual help to the baby\&apos;s head. Acta Obstet Gynecol Scand. 1998; 77(10): 974-7.

9. Fowler GE. Risk factors for and management of obstetric anal sphincter injury. Obstet Gynecol Rep Med. 2010; 20(8): 131-6.

10. Jandér $C$, Lyrenäs $S$. Third and fourth degree perineal tears. Acta Obstet Gynecol Scand. 2001; 80: 229-34.

11. Santoso BI. Budi Iman Santoso Assessment (BISA): a model for predicting levator ani injury after vaginal delivery. Med J Indones. 2012; 21: 102-7.

12. Parnell C, Langhoff-Roos J, Moller H. Conduct of labor and rupture of the sphincter ani. Acta Obstet Gynecol Scand. 2001; 80(3): 256-61.
13. O' Herlihy C. Obstetric perineal injury: Risk factors and strategies for prevention. Semin Perinatol. 2003; 27(1): 13-9.

14. Eason E, Labrecque M, Wells G, Feldman P. Preventing perineal trauma during childbirth: a systematic review. Obstet Gynecol. 2000; 95(3): 464-71.

15. Pyykönen A, Gissler M, Jakobsson M, Lehtonen L, Tapper A-M. The rate of obstetric anal sphincter injuries in Finnish obstetric units as a patient safety indicator. Eur J Obstet Gynecol Reprod Biol. 2013; 169(1): 33-8.

16. Räisänen SH, Vehviläinen-Julkunen K, Gissler M, Heinonen S. Lateral episiotomy protects primiparous but not multiparous women from obstetric anal sphincter rupture. Acta Obstet Gynecol Scand 2009; 88(12): 1365-72.

17. Andrews V, Sultan AH, Thakar R, Jones PW. Risk factors for obstetric anal sphincter injury: A prospective study. Birth. 2006; 33(2): 117-22.

18. Christianson LM, Bovbjerg VE, McDavitt EC, Hullfish KL. Risk factors for perineal injury during delivery. Am J Obstet Gynecol. 2003; 189(1): 255-60.

19. Sellars D. Business Plan Project: A Step-by-Step Guide to Writing a Business Plan. 1 ed: Business Expert Press; 2009.

20. Fernando RJ, Sultan AH. Risk factors and management of obstetric perineal injury. Obstet Gynecol Reprod Med. 2004; 14(5): 320-6.

21. Kaye S. The Value of Audit in Clinical Practice. Physiotherapy. 1991; 77(10): 705-7.

22. Andrews V, Thakar R, Sultan AH. Outcome of obstetric anal sphincter injuries (OASIS)-role of structured management. Int Urogynecol J Pelvic Floor Dysfunct. 2009; 20(8): 973-8.

23. Fischer W. Urgencies and DRGs. BMC Health Services Research. 2010; 10(Suppl 2): A12.

24. Fernando RJ, Sultan AH, Kettle C, Radley S, Jones P, O'Brien PM. Repair techniques for obstetric anal sphincter injuries: a randomized controlled trial. Obstet Gynecol. 2006; 107(6): 1261-8.

25. El-Talatini MR, Taylor AH. Re-audit of third and fourth degree perineal tears at Lincoln Districs General Hospital (e-poster). 2011 [cited 2015 Dec 21];1. Available from: http://epostersonline.s3.amazonaws.com/rcog2013/rcog 2013.4890308.NORMAL.pdf 